at Foyle College, Londonderry and Trinity College, Dublin, where he graduated B.A., M.B. and B.Ch. in 1887. He won the travelling medical scholarship at Trinity in 1887, studied in Vienna, and took the diploma in State Medicine of his university in 1888. After holding the posts of resident surgeon at Sir Patrick Dunn's Hospital and at the National Eye and Ear Hospital in Dublin, he entered the Indian Medical Service in October, 1887.

His first four years in the service were spent in military duty, during which time he served in the ChinaLushai campaign of 1889-90, gaining the N. E. frontier medal and clasp. Attaining to civil employment in 1892, he first served as civil surgeon of Midnapore, and then joined the Jail Department. For the next twenty-seven years his activities centred on two subjects, the improvement of the prisons of Bengal, and the Indian Medical Gasette, which he edited for twenty years. The success of this journal is indeed largely due to the labours of its two most brilliant editors, the late Colonel Kenneth McI,eod, who edited it from 1871 to 1892 , and Sir Walter Buchanan, who edited it from 1899 until his retirement from the service in 1919. The Gasette was fortunate in getting into the hands of this very able organizer. His great literary ability and taste were apparent from the moment he took over charge, and the circulation and influence of the Gasette improved enormously.

In the Jail Department, Sir Walter Buchanan's activities were untiring. He served in turn as Superintendent of Bhagalpur Central Jail, for a short time as Superintendent of Alipore Central Jail, and was appointed Inspector-General of Prisons, Bengal in 1902,-a post which he held for seventeen years until his retirement. Under his administration, the sanitation of the Bengal prisons was enormously improved, whilst the death rates were substantially reduced. His fine work in the department was recognised by the award of the C.I.E. in 1913, and promotion to K.C.I.E. in 1918. He was on the Indian Prisons' Commission of 1919-20, and much of the value of the reforms introduced by that Commission, -reforms which are to-day making for material improvement in the prisons of India,-was due to Sir Walter Buchanan's labours.

Among other publications, he was the author of The Darvinism of To-day, 1881; the Jail Mamual, 1898; the article on inflammation of the liver in the third edition of Quain's Dictionary of Medicine, 1902; and the chapter on Indian medical jurisprudence in the fifth edition of Taylor's Medical Jurisprudence, 1905. He married a rlaughter of the late Mr. E. Simpson Byrne; she died in 1916. He leaves one son,-an officer in the Royal Scots Fusiliers.

After his retirement from India, he served for three vears as a member of the Central Council of the British Medical Association, and of its Naval and Militarv Committee-where his influence was marked in the surcessful efforts made by that Association to secure improvements in the status and pay of the Indian Medical Service. His deep interest in the Service was maintained after his retirement, - and in establishing the Walter Buchanan Scholarship at Epsom College for the sons of medical men, he made it clear that perference would be given to the sons of I.M.S. officers. In a letter received from him a year ago he commented upon what he considered to be the improvement in the Indian Medical Gasette, but added the characteristic comment "Don't. neglect the Service Notes."

Sir Walter was of an extremely genial dispositition and his personal popularity was great. Late in life he took an interest in freemasonry and attacked the subject with characteristic energy. He became Master of Lodge Everest and it was a great treat to see him at his duty. $\mathrm{He}$ was more than usually efficient, whilst his rich Irish accent and natural gift for oratory greatly helped the general effect.

Residing for many years at the United Services Club, Calcutta, he was a delightful and entertaining host. He was a keen fisherman and an enthusiastic golfer. Sir Walter was intensely energetic in everything he took up and it was with genuine regret he left India and the work which he loved so well. He was a pessimist to the end as to the future of the Service he adorned for so long. His death adds another name to the long roll of honour of Bengal officers whose devoted labours on behalf of India have been followed by but a few scanty years of leisured retirement. Major F. W. Cragg, M.D., D.sc. (Edin.), F.R.S.E., F.E.S.,
I.M.S.

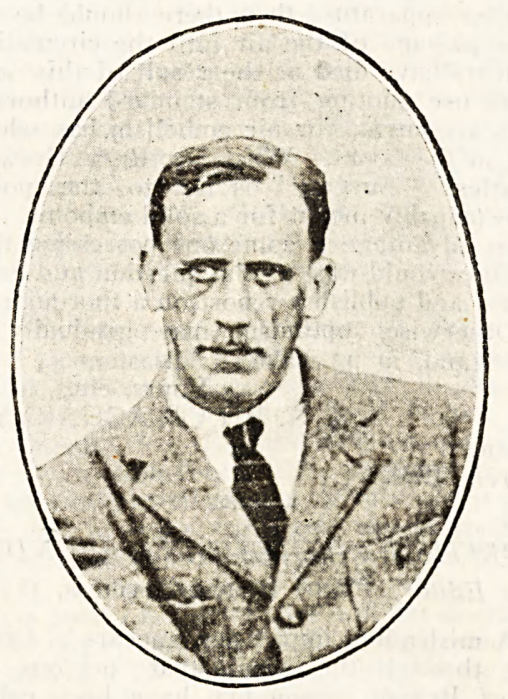

IT is with the deepest regret that we learn of the tragic death of Major F. W. Cragg, I.M.s., from typhus fever at Lahore on the 23rd of April, 1924. Major Cragg's death adds another name to the long but brilliant list of scientific investigators who have lost their lives in the prosecution of medical enquiries for the benefit of humanity. He died as truly on active service as did any officer killed in the Great War.

Francis William Cragg was born on the 19th of May, 1882, and was educated at Edinburgh University, where he took the M.D., and-in later life-the D.Sc. degrees. Entering the Indian Medical Service on the 1st ot September 1906, after spending the usual period in military duty, he was posted to the King Institute of Preventive Medicine at Guindy, and gave early promise of a brilliant career. His industry was enormous and his technical and medical abilities were of a very high order,-in fact he was one of the three leading medical entomologists in the country. At Madras he came into association with Major W. S. Patton; I.M.S., and the combined work of both authors led to the publication in 1913 of Patton and Cragg's Text-Book of Medical Entomologv-which is to-day the greatest testimony to the work and abilities of both authors.

Transferred in 1913 to the Central Research Institute at Kasauli, Cragg soon secured admission to the Medical Research Department, and became a regular contributor of a series of most valuable entomological papers to the Indian Journal of Medical Research. In 1914 on the outbreak of the Great War he was recalled to militarv duty. His war service was mostly performed in Egypt and Bombay. As a military medical officer, when attached to a hospital train and again when doing the administrative sanitary work of a brigade, Cragg performed his duties in the extremely thorough way which was so characteristic of the man. As pathologist to the Victoria War Hospital, Bombay, he worked with intense energy, -contributing a valuable series of papers to the Indian Journal of Medical Research on amœbic dysentery, intestinal protozoal infections and aberrant types of malarial parasites. 
From Bombay he reverted to his post as one of the Assistant Directors at the Central Research Institute, Kasauli, and commenced work which resulted in a further series of entomological papers of great value. Throughout the whole of his entomological papers, however, detailed and technical they might be,-Cragg never lost sight of their bearings upon wider and more general problems. He would ever revert to the biological laws and principles underlying his research. One of the most noteworthy of his contributions to medical literature, for instance, is his series of papers in 19201923 upon the distribution of the Indian species of rat fleas, in which he shewed the correlation of the prevalence of Xenopsylla cheopis with plague, and the absence of correlation of $X$. astia and $X$. braziliensis with plague, $-a$ paper with a wide practical bearing, since a study of the species of rat fleas prevalent in any locality may determine its susceptibility or otherwise to plague.

In 1921 he set to work upon the problems of relapsing fever in the United Provinces, and reverted to the same subject in 1922 on his return from leave. In a series of most important papers he demonstrated the epidemiology of the disease in the United Provinces, experimentally proving its transmission by lice, and shewing how the epidemic years were associated with an abnormally low temperature and abnormally high humidity during the spring months, which prevent the annual delousing of the population that usually occurs with the onset of the hot weather, and prolonging the life of the pediculi concerned. During this investigation, he contracted a severe attack of relapsing fever himself-an attack which weakened a constitution already impaired by years of overwork and attacks of malaria.

In spite of ill-health, however, Cragg remained vigorously at work. The problem of the existence of typhus fever in India, and especially of its importation into India over the North West Frontier came up for consideration, and, at his own request, Cragg was deputed to study it in December 1923. Proceeding to Kashmir, he shewed that some at least of these epidemics of "typhus" fever were, in reality, epidemics of relapsing fever, especially that in the Lolab Valley. Another epidemic, however, which was raging among villages on the road up to the Kashmir Valley, presented peculiar features Its clinical features were those of typhus, but in other ways it differed from the classical description, and Cragg proceeded to Uri to study it. Here he contracted his fatal illness in the ill-lighted, ill-ventilated, insanitary hovels of the people who were the subjects of the epidemic under investigation. $\mathrm{He}$ was taken to Lahore, and the seriousness of his illness was scarcely at first realised. Realising the importance of establishing whether it was typhus or relapsing fever, Cragg himself insisted until he lost consciousness on the fullest notes of his own case being taken. It was only towards the very end of his illness that the Weil-Felix reaction became positive. It is sad to record his death from the very disease which he was investigating. It was hoped that he would have joined the kala-azar commission which is about to be appointed to investigate the mode of transmission of the disease as entomologist, and his loss in this connection also will be severely felt.

In Major Cragg, India loses one of her few really brilliant entomologists, and his loss can ill be spared. He was a rapid, accurate and most painstaking worker. His energy was enormous, and he would often work far into the night. Socially, he was a delightful companion and host, and gifted with a keen sense of humour. He was an ardent follower of the cult of physical exercise, very fond of walking, and an excellent shot with both gun and rifle.

Major Cragg leaves a widow and two children, who are in England. To them we convey the sympathy of the whole Service in India. India can ill spare the loss of one of her most distinguished and brilliant medical research workers. We trust that Government will mark its appreciation of the devoted service which he rendered
to this country.

\section{APPOINTMENTS AND Transfers.}

ON retur' from leave, Lieutenant-Colonel H. B. Steen, M.D., I.M.S., Civil Surgeon, did general duty at the Medical College Hospitals, Calcutta, from the forenoon of the 29th February 1924 to the afternoon of the 16th March 1924.

Major (now Lieut.-Colonel) R. M. Barton, D.s.o., I.M.s., to be acting Lieutenant-Colonel from 22nd July 1916 to 18th October 1919, whilst commanding a Casualty Clearing Station, Mesopotamia.

Major 'T. L. Bömford, M.B., I.M.S., is appointed to act as a Civil Surgeon and is posted temporarily to Murshidabad, vice Lieutenant-Colonel A. H. Proctor, D.s.o., I.M.s., transferred.

Major H. H. King, I.M.S., is appointed to officiate as Assistant Director, Central Research Institute, Kasauli.

Major J. A. Sinton, I.M.S., is appointed to officiate as Assistant Director, Central Research Institute, Kasauli, vice Lieutenant-Colonel S. R. Christophers, C.I.E., O.E.E.. I.M.S., detailed for research work under the Indian Research Fund Association with effect from the date on which he assumes charge of his duties.

Major W. Ross Stewart, Indian Medical Service, Staff Surgeon, Bangalore, is appointed, in addition to his own duties, to officiate as an Agency Surgeon and is posted as Residency Surgeon, Mysore, during the absence on leave of Lieutenant-Colonel R. F. Standage, C.I.E., I.M.S.

Major A. G. Tressider, M.D., I.M.S., is appointed to officiate as Surgeon to His Excellency the Governor of Bombay, with effect from the forenoon of 15 th March 1924 during the absence of Lieutenant-Colonel G. J. Grafton Young, I.M.s., on leave.

The services of Captain C. J. Lodge-Patch, м.c., I.M.s., are placed permanently at the disposal of the Government of the Punjab, with effect from the date on which he is confirmed as Superintendent of the Punjab Lunatic Asylum, Lahore.

The services of Captain J. M. R. Hennessy, r.M.s., are placed temporarily at the disposal of the Government of the Punjab for employment in the Jail Department, with effect from the date on which he assumes charge of his duties.

Captain J. F. Holmes, I.M.S., to be acting LieutenantColonel whilst holding appointments with Mesopotamian Expeditionary Force from 10th to 15th August 1918 and from 1st December 1919 to 1st February 1920.

Captain W. C. Spackman, M.R.C.S., L.R.C.P. (Lond.), M.B., B.S. (Lond.), D.T.M. (Lond.), I.M.S., is appointed to act as Civil Surgeon, Nasik, with effect from the forenoon of 27th March 1924.

\section{LEAVE.}

Lieutenant-Colonel H. B. Steen, I.M.S., was granted by the High Commissioner for India furlough for two months, in extension of the combined leave sanctioned in Notification No. 2843-Medl., dated the 2nd November 1921.

Lieutenant-Colonel H. B. Steen, I.M.S., is granted furlough for three days from the 10th to the 12th November 1922, in extension of the furlough for two months granted to him by the High Commissioner for India.

Lieutenant-Colonel G. McPherson, c.I.E., I.M.S., has been granted a further extension of leave for four months on medical certificate with effect from the 20th May 1924.

In modification of Government Notification No. S. $20 \mid 10$, dated the 19th December 1923, Lieutenant-Colonel R. W. Anthony, r.M.s., is granted, with effect from the 9th March 1924, leave on average pay for seven months and twenty-five days combined with leave on half average pay for six days.

In modification of Government Notification No. S. 20|16, dated the 21st February 1924, Lieutenant-Colonel H. M. H. Melhuish, I.M.s., Acting Director of Public Health, has been granted leave for six months with effect from the 30th March 1924, 